\title{
Manifestações eletrofisiológicas em adultos com HIV/AIDS submetidos e não-submetidos à terapia anti-retroviral ${ }^{* * * *}$
}

\author{
Electrophysiological manifestations in adults with HIV/AIDS \\ submitted and not submitted to antiretroviral therapy
}

\author{
Carla Gentile Matas* \\ Sara Manami Silva** \\ Bruna de Almeida Marcon** \\ Isabela Crivellaro Gonçalves***
}

*Fonoaudióloga. Doutora em Distúrbios da Comunicação Humana pela Universidade Federal de São Paulo - Escola Paulista de Medicina. Professora Associada do Curso de Fonoaudiologia da Faculdade de Medicina da Universidade de São Paulo (FMUSP). Endereço para correspondência: Rua Cipotânea, 51 São Paulo - SP - CEP 05360-160 (cgmatas@usp.br).

**Fonoaudióloga. Especialização em Audiologia pelo Curso de Fonoaudiologia do Departamento de Fisioterapia, Fonoaudiologia e Terapia Ocupacional da FMUSP.

***Fonoaudióloga. Mestre em Ciências pelo Programa de Pós-Graduação em Ciências da Reabilitação - Área de Concentração: Comunicação Humana do Departamento de Fisioterapia, Fonoaudiologia e Terapia Ocupacional da FMUSP.

****Trabalho Realizado no Laboratório de Investigação Fonoaudiológica em Potenciais Evocados Auditivos do Curso de Fonoaudiologia do Departamento de Fisioterapia, Fonoaudiologia e Terapia Ocupacional da FMUSP.

Artigo Original de Pesquisa

Artigo Submetido a Avaliação por Pares

Conflito de Interesse: não

Recebido em 25.05.2009.

Revisado em 15.12.2009; 18.12.2009.

Aceito para Publicação em 22.04.2010.

\begin{abstract}
Background: auditory evoked potentials (AEP) assess the neuroelectric activity on the auditory pathway - from the auditory nerve to the cerebral cortex - in response to an acoustic stimulus or event. Studies have demonstrated electrophysiological abnormalities in individuals with HIV/AIDS. Aim: to characterize the hearing electrophysiological manifestations in adults with HIV/AIDS by comparing the results obtained in the group exposed to antiretroviral therapy with those obtained in the group not exposed to such treatment. Method: electrophysiological evaluation of hearing (Auditory Brainstem Response - ABR, Auditory Middle Latency Reponse - AMLR and P300) was conducted in 56 individuals with HIV/AIDS: 24 participants composed group I (not exposed to antiretroviral treatment) and 32 participants composed group II (exposed to treatment). Results: alterations in every AEP were observed in individuals with HIV/ AIDS, especially in the ABR. Indeed, the group exposed to antiretroviral treatment presented more alterations. Conclusion: individuals with HIV/AIDS may present alterations on the central and peripheral auditory nervous system. The group exposed to antiretroviral therapy presents more alterations on the brainstem auditory pathway.
\end{abstract}

Key Words: HIV; Antiretroviral Therapy; Highly Active; Hearing; Evoked Potentials; Auditory.

\section{Resumo}

Tema: os potenciais evocados auditivos (PEA) avaliam a atividade neuroelétrica na via auditiva, desde o nervo auditivo até o córtex cerebral, em resposta a um estímulo ou evento acústico. Estudos demonstram anormalidades eletrofisiológicas em indivíduos com HIV/AIDS. Objetivo: caracterizar as manifestações eletrofisiológicas da audição em adultos com HIV/AIDS, comparando os resultados obtidos no grupo exposto a tratamento anti-retroviral com os obtidos no grupo não exposto a tratamento. Método: realizada avaliação eletrofisiológica da audição (PEATE, PEAML e P300) em 56 indivíduos portadores do HIV/AIDS, sendo 24 do Grupo I (não expostos ao tratamento anti-retroviral) e 32 do Grupo II (expostos ao tratamento). Resultados: foram encontradas alterações em todos os PEA nos indivíduos com HIV/AIDS, principalmente no PEATE; sendo que neste, o grupo exposto ao tratamento antiretroviral apresentou mais alterações. Conclusão: indivíduos com HIV/AIDS podem apresentar alterações no sistema nervoso auditivo periférico e central, sendo que o grupo exposto a tratamento anti-retroviral apresenta mais alterações na via auditiva em tronco encefálico.

Palavras-Chave: HIV; Audição; Terapia Anti-retroviral de Alta Atividade; Potenciais Evocados Auditivos.

Referenciar este material como:

Matas CG, Silva SM, Marcon BA, Gonçalves IC. Electrophysiological manifestations in adults with HIV/AIDS submitted and not submitted to antiretroviral therapy $\checkmark$ (original title: Manifestações eletrofisiológicas em adultos com HIV/AIDS submetidos e não-submetidos à terapia anti-retroviral). Pró-Fono Revista de Atualização Científica. 2010 abr-jun;22(2):107-12. 


\section{Introduction}

The Acquired Immune Deficiency Syndrome (AIDS) is caused by the human immunodeficiency virus (HIV), a specific retrovirus that affects the immune system. Nowadays, the most commonly used treatment for infected individuals is the Highly Active Anti-Retroviral Therapy (HAART), which consists on the use of at least three drugs and the monitoring of the plasma viral concentration (1). A high incidence of hearing impairment is observed in patients with HIV / AIDS. The possible etiological factors are the direct action of the virus, the opportunistic infections and the use of drugs (2).

Auditory evoked potentials (AEP) assess neuroelectrical activity on central auditory pathways (3) and are of great importance in audiological practice. The AEP are objective and non-invasive tests that complement the routine procedures in the diagnosis of hearing disorders. Studies with AEP have shown electrophysiological abnormalities in individuals with HIV / AIDS, mainly on the Auditory Brainstem Response (ABR) $(4,5)$ and on the cognitive potential (P300) (6.7) . Such abnormalities have been reported even before the clinical onset of symptoms - such as neurological and cognitive deficits- that are part of the AIDS dementia complex (8). Serafini et al. (9) emphasize the efficacy of using these tests to better define the extent of brain damage in patients infected by HIV, allowing the monitoring of the speed of evolution of these lesions.

In view of the foregoing considerations, this study aimed to characterize the auditory electrophysiological manifestations in adults with HIV / AIDS, comparing the results obtained in the group exposed to antiretroviral treatment with those obtained in the group not exposed to such treatment.

\section{Methods}

Institutional review board approval for this study was obtained from CAPPesq - HC FMUSP registered under protocol number 1026/04.

The study participants were referred by the House of AIDS - Zerbini Foundation and received clarification about this research and, after agreeing to participate, signed a consent form.

The sample was composed by 56 individuals with HIV / AIDS aged between 18 and 58 years old. Twentyfour individuals not exposed to antiretroviral treatment were included in group I and 32 individuals exposed to antiretroviral treatment were included in group II. Participants who fulfilled the following criteria were excluded from the sample: pregnancy; presence of active opportunistic infections or other clinical impairment and / or cognitive impairment that would prevent or interfere on the achievement of audiological and / or electrophysiological tests. Considering the audiological profile of the participants, 3.5\% had isolated hearing loss at $8 \mathrm{kHz}, 12.5 \%$ had sensorioneural hearing loss, $7.1 \%$ conductive hearing loss, 3.5\% mixed hearing loss and $8.9 \%$ high frequency hearing loss.

Electrophysiological assessment was initiated with the P300 and next we performed the ABR and the auditory middle latency response (AMLR). The following equipments were used to perform this assessment: portable "Traveler Express" from "Biologic"; five surface electrodes; TDH-39 headphones; abrasive skin cleanser and electrolyte paste to facilitate the recording of auditory evoked potentials; and microporous tape for fixation of the electrodes. After cleaning the skin, the electrodes werefixed to the skinin predeterminedpositions, according to the standard International Electrode System (IES) 1020 (10). The impedance values of the electrodes were below $5 \mathrm{kOhms.}$

For the ABR, the stimulus was the click, rarefaction polarity, presented monaurally at $80 \mathrm{dBnHL}$, at a presentation rate of 19 clicks per second and a total of 2000 stimuli. We obtained two recordings on each ear. The electrodes were placed at the vertex $(\mathrm{Cz})$ and at the right and left ears (A2 and A1). The absolute latencies of waves I, III, V, and I-III, III-V and I-V interpeaks were analyzed. The results were classified as normal or abnormal, according to the normal range for the age group studied proposed by the equipment manual. The abnormalities were described as middle ear, sensory, lower brain stem, higher brain stem, and associated peripheral and central impairments.

For the AMLR, the stimulus was the click, presented monaurally at $70 \mathrm{dBnHL}$, with a presentation rate of 10 clicks per second and a total of 1000 stimuli. The electrodes were placed at Fpz, A2, A1 and right and left temporoparietal junctions (C4 and C3). We analyzed the values of $\mathrm{Na}$-Pa amplitude at the derivations studied. A difference of less than or equal to $50 \%$ between amplitudes obtained when comparing the ipsilateral and contralateral derivations two by two (C3/A1, C4/A2, C3/ A2, C4/A1) was indicative of normality. The abnormalities were classified as electrode effect and ear effect (11). The classification "Both" was used when the individual simultaneously presented the two types of abnormalities.

For the P300, the stimulus was the tone burst at 1000 and $1500 \mathrm{~Hz}$, presented monaurally at 75nHL, at a presentation rate of 1.1 stimuli per second and a total of 300 stimuli. The electrodes were placed at Cz,A2,A1 and forehead (Fpz). The individual was instructed to pay attention and count the number of rare stimuli $(1500 \mathrm{~Hz})$ within a series of frequent stimuli $(1000 \mathrm{~Hz})$. The value of 
the P300 wave was considered for analysis. The waves were analyzed according to normal values proposed by McPherson (12). The results were classified as normal or abnormal, and the types of abnormalities were described as increased latency and absence.

Statistical analysis included the chi-square and the Fisher's exact test. The adopted significance level was $5 \%$. Individuals were considered abnormal if they presented at least one abnormality, i.e., unilateral or bilateral. Of the 32 patients in group II, five were not submitted to AMLR and P300 due to lack of time or difficulties in executing AEP.

\section{Results}

The results obtained on the electrophysiological hearing tests are presented below. Table 1 refers to the results obtained on the ABR.

According to Table 1, 32 (57.1\%) individuals with HIV / AIDS presented abnormal results. A higher percentage of abnormal results was verified in group II (62.5\%) when compared to group I (50\%), however with no statistically significant between groups difference $(p=0.350)$. Abnormalities that reflect impairments in the peripheral and central levels separately or simultaneously in the same individual were observed in groups I and II. Among the assessed individuals with HIV / AIDS, 12.5\% presented ABR responses that were suggestive of middle ear involvement (4.2\% in group I and 18.75\% in group II); 8.9\% suggestive of sensory impairment (8.3\% in group I and $9.4 \%$ in group II); $25.0 \%$ suggestive of low brainstem impairment (33.3\% in group I and 18.75\% in group II); 5.35\% suggestive of high brain stem impairment (9.4\% in group II); and $5.35 \%$ suggestive of associated peripheral and central impairments (4.2\% in group I and 6.2\% in group II). It is noteworthy that $28.8 \%$ of abnormal results on ABR could be explained by the hearing impairment assessed by conventional audiometry and / or acoustic immittance measures whereas $19.6 \%$ with normal audiometry and acoustic immittance measures showed abnormalities in ABR.

The AMLR results are shown in Table 2.

In AMLR, 54.9\% of individuals with HIV / AIDS presented abnormal results. Although a statistically significant between groups difference was not observed regarding the occurrence of normal and abnormal results ( $\mathrm{p}=0.642$ ), a higher number of individuals with abnormalities in group I (58.3\%) was observed (Table 2). With regard to the types of abnormalities observed on AMLR (electrode effect, ear effect or both), there was no statistically significant difference between groups, but a higher occurrence of electrode effect could be observed in both groups (50\% in group I and $42.8 \%$ in group II).

The P300 results - which were subsequently classified as increased or absent - are presented below (Table 3).

In the P300 analysis, $19.6 \%$ of the participants showed results with abnormalities. The groups did not statistically differ with regard to the occurrence of normal and abnormal results (Table 3). The occurrence of normal results was predominant in both groups (79.1\% in group I and $81.4 \%$ in group II). No statistically significant between groups difference was observed regarding the type of abnormalities on P300. Both groups presented higher percentages of increased latencies - 80\% in group I and $60 \%$ in group II. It is noteworthy that only $20 \%$ of abnormal results of the P300 might be explained by the hearing loss detected by conventional audiometry. 
TABLE 1. Distribution of occurrence of normal and abnormal ABR results in both groups.

\begin{tabular}{|c|c|c|c|c|}
\hline \multirow{2}{*}{ ABR } & \multicolumn{3}{|c|}{ GI } & \multicolumn{2}{c|}{ GII } \\
\cline { 2 - 5 } & $\mathrm{N}$ & $\%$ & $\mathrm{~N}$ & $\%$ \\
\hline Normal & 12 & 50 & 12 & 37,5 \\
\hline Abnormal & 12 & 50 & 20 & 62,5 \\
\hline \multicolumn{5}{|c|}{$X^{2}=0,875 ;$ n.df. $=1 ; \mathrm{p}=0,350$} \\
\hline
\end{tabular}

Note: $\mathrm{N}=$ number of participants.

TABLE 2. Distribution of occurrence of normal and abnormal AMLR results in both groups..

\begin{tabular}{|c|c|c|c|c|}
\hline \multirow{2}{*}{ AMLR } & \multicolumn{2}{|c|}{ GI } & \multicolumn{2}{c|}{ GII } \\
\cline { 2 - 5 } & $\mathrm{N}$ & $\%$ & $\mathrm{~N}$ & $\%$ \\
\hline Normal & 10 & 41,6 & 13 & 48,1 \\
\hline Abnormal & 14 & 58,3 & 14 & 41,8 \\
\hline & \multicolumn{5}{|c|}{$X^{2}=0,216 ; \mathrm{df} .=1 ; \mathrm{p}=0,642$} \\
\hline
\end{tabular}

Note: $\mathrm{N}=$ number of participants

TABLE 3. Distribution of occurrence of normal and abnormal P300 results in both groups.

\begin{tabular}{|c|c|c|c|c|}
\hline \multirow{2}{*}{ P300 } & \multicolumn{2}{|c|}{ GI } & \multicolumn{2}{c|}{ GII } \\
\cline { 2 - 5 } & N & $\%$ & N & $\%$ \\
\hline Normal & 19 & 79,1 & 22 & 81,4 \\
\hline Abnormal & 5 & 20,8 & 5 & 18,5 \\
\hline & \multicolumn{5}{|c|}{$X^{2}=0,043$; n.g.l. $=1 ; \mathrm{p}=0,835$} \\
\hline
\end{tabular}

Note: $\mathrm{N}$ = number of participants 


\section{Discussion}

According to the results described on the three electrophysiological assessments, it can be noted that for both groups a high occurrence of abnormal results (Tables 1 and 2), with no statistically significant differences between groups, was observed on ABR and AMLR. In contrast, a higher percentage of normal results for both groups (Table 3) was observed on the P300.

Considering the ABR results and taking into account that only $28.8 \%$ of the abnormalities could be attributed to hearing loss detected in pure tone audiometry, the fact that a greater number of individuals presented abnormal results shows that the auditory structures can be affected even in early stages of the disease, with absence of clinical manifestations. Literature (2) states that such abnormalities may result from the direct action of the virus, secondary infections or ototoxic drugs. Ahigher percentage of abnormal results in the group of participants exposed to treatment (62.5\%) when compared to Group I (50\%) was also observed (Table 1). However, this difference was not statistically significant. Such findings corroborate to those reported by Mata Castro et al. (13). In that study, when assessing the hearing function of HIV-infected individuals, the authors reported that abnormal BAEP was the most commonly observed electrophysiological hearing disorder, especially in advanced stages of the disease - i.e., individuals who were exposed to anti-retroviral treatment.

Amongst the ABR abnormalities, the most frequently observed type in both groups was the lower brainstem impairment, characterized by increased absolute latencies of waves III and V and I-III and I-V interpeaks. This finding corroborates to those described by Bankaitis et al. (11). Other abnormalities could be observed in the present and other studies, such as increased latencies of waves I, III and V $(5,15)$ and I-V interpeak $(16,17)$. We observed, in both groups, results that are indicative of abnormalities resulting from CNS involvement (low and high brainstem alterations). This may indicate that both the brainstem structures and the auditory nerve are the first structures to be affected by the HIV virus due to the ototoxic effect or immunosuppression causing damage to the auditory pathway and significant losses in the transmission of auditory information.

Agreeing to other authors, we observed ABR findings suggestive of middle ear involvement, especially in the group exposed to antiretroviral treatment $(18,19,20)$. According to the literature, the immunosuppression is one of the main factors responsible for susceptibility to infections of the middle ear in individuals with HIV / AIDS.

Currently, the AMLR has been considered one of the best tests to evaluate the central auditory nervous system and the central auditory processing disorders due to the location of their generators and because its appearance requires integrity of auditory cortical and subcortical areas (21). The high number of abnormal AMLR results in individuals with HIV / AIDS can be justified by the fact that one of the first changes in the CNS of HIV patients is characterized by demyelination at subcortical level, even without clinical evidence of neurological problems (22). The comparison between groups I and II revealed a higher percentage of abnormal results in group I (58.3\%) as compared to group II (51.8\%) (Table 2) with the electrode effect being the most frequently observed one in both groups. Therefore, we can see that individuals with HIV / AIDS, regardless of exposure to antiretroviral treatment, may show abnormalities in central auditory pathways suggesting lesional (electrode effect) or functional (ear effect) impairments, which are often not identified through conventional audiological assessment. Few studies in the literature investigate the AMLR in individuals with HIV / AIDS. The studies that investigate electrophysiological manifestations in this population are mainly focused on ABR and P300.

Regarding the P300, a higher percentage of abnormal results was observed in group I (20.8\%) as compared to group II (18.5\%) (Table 3). For both groups, the most commonly observed abnormality was the increased latency - in agreement with other studies that have studied this potential in the same population $(23,24)$. Abnormalities in the P300 before the clinical onset of symptoms - such as neurological and cognitive deficits, which are part of the AIDS dementia complex $(8,25)$ - are reported by several studies $(14,4)$

On the AMLR and P300 analysis, the percentage of abnormalities was higher for group I when compared to group II, and the values obtained for the two groups were very similar. Thus, although individuals from Group II were clinically more affected than those from Group I, the results presented by them were not significantly worse. Therefore, such data may indicate that abnormalities in central auditory pathways, as verified by the AEP, may be more related to HIV infection, i.e., such responses are not potentially affected by the action of ototoxic drugs used in antiretroviral therapy. Similarly, Vieira et al. (26) found no correlation between ototoxicity and antiretroviral therapy once there were not statistically significant 
differences regarding the prevalence of hearing loss in individuals exposed and not exposed to treatment.

Considering the high occurrence of abnormalities in central auditory nervous system in individuals with HIV / AIDS, it is important to carry out AEP studies aiming to assess the auditory system function and the degree of injury, allowing the understanding of the effects caused by virus infection and the monitoring of injury degree. We emphasize that electrophysiological tests complement the routine procedures in the diagnosis of hearing disorders. Given that the central nervous system and immune system are the main targets of HIV infection and the higher occurrence of abnormalities in auditory evoked potentials observed in this study, the auditory electrophysiological tests are important instruments in detecting early signs of neurological degeneration that precede the clinical manifestations in individuals with HIV / AIDS

\section{References}

1. Montaner JSG, Hogg RS, O’Shaughnessy MV. Emerging international consensus for use of anti-retroviral therapy. Lancet. 1997;349:1042.

2. Roland Jr JT, Alexiades G, Jackman AH, Hillman D, Shapiro W. Cochlear Implantation in Human Immunodeficiency Virus - Infected Patients. Otol \& Neurotol. 2003;24(6):892-5.

3. Junqueira CAO, Colafêmina JF. Investigação da estabilidade inter e intra-examinador na identificação do P300 auditivo: análise de erros. Rev Bras Otorrinolaringol. 2002;68(4):468-78.

4. Reyes-Contreras L, Silva-Rojas A, Ysunza-Rivera A, Jimenez-Ruiz G, Berruecos-Villalobos P, Romo-Gutierrez G. Brainstem auditory evoked response in HIV - infected patients with and without AIDS. Arch Med Res. 2002; 33(1):25-8.

5. Castello E, Baroni N, Pallestrini E. Neurotological auditory brain stem response findings in human immunodeficiency virus- positive patients without neurologic manifestation. Ann Oto Rhinol Laryngol. 1998; 107(12):1054-60.

6. Goodin DS, Aminoff MJ, Chernoff DN, Hollander H Long latency event-related potentials in patients infected with human immunodeficiency virus. Ann Neurol. 1990; 27(4):414-9.

7. Fein G, Biggins CA, MacKay S. Delayed latency of the event-related brain potential P3A component in HIV disease. Progressive effects with increasing cognitive impairment. Arch Neurol. 1996;53(8):715-6.

8. Ollo C, Johnson R, Grafman J. Signs of cognitive change in HIV disease: an event-related brain potential study. Neurology. 1991;41:209-15.

\section{Conclusion}

Individuals with HIV / AIDS show abnormalities on AEP, most frequently on the ABR, suggesting impairments of synchrony in the generation and transmission of neural impulses along the auditory pathway in the brainstem. These individuals also show abnormalities on AMLR and P300, suggesting impairments of the auditory subcortical and cortical regions. Individuals with HIV / AIDS exposed to antiretroviral therapy present more ABR abnormalities when compared to individuals not exposed to treatment.
9. Serafini G, Stagni G, Chiarella G, Brizi S, Simoncelli C. ABR and HIV - induced impairment of the central nervous system. Rev Laryngol Otol Rhinol. 1998;119(2):87-90.

10. Jasper HA. The ten-twenty system of the International Federation. Electroencephalogr Clin Neurophysiol. 1958; 10:371-5.

11. Musiek FE, Lee WW. Potenciais auditivos de média e longa latência. In: Musiek FE, Rintelmann WF, editores. Perspectivas atuais em avaliação auditiva. Barueri: Manole; 2001. p. 239-56.

12. McPherson DL. Late potentials of the auditory system. San Diego: Singular Pub Group; 1996.

13. Mata Castro N, Yebra Bango M, Tutor de Ureta P, Villarreal Garcia-Lomas M, Garcia Lopez F. Hearing loss and human immunodeficiency virus infection. Study of 30 patients. Rev Clin Esp. 2000;200(5):271-4.

14. Bankaitis AE, Christensen LA, Murphy G, Morehouse CR. HIV/AIDS and auditory evoked potentials. Seminars in Hearing. 1998;19(2):177-93.

15. Pierelli F, Garrubba C, Tilia G, Parisi L, Fattaposta F, Pozzessere G, Soldati G, Stanzione P, D'Offizi G, Mezzaroma I. Multimodal evoked potentials in HIV-1 seropositive patients: relationship between the immune impairment and the neurophysiological function. Acta Neurol Scand. 1996; 93(4):226-71.

16. Reyes A, Ysunza A, Silva A, Jiménez G, Berruecos P, Romo G. Potenciales provocados auditivos de latencia corta en pacientes infectados por virus de inmunodeficiencia humana. Resultados preliminares. An otorrinolaringol mex. 1999;44(1):3-7.

17. Somma-Mauvais H, Farnarier G. Evoked potentials in HIV infection. Neurophysiol Clin. 1992;22(5):369-84. 
18. Gold S, Tami TA. Otolaryngological manifestations of HIV/AIDS. Seminars in Hearing. 1998;19(2):165-75.

19. Prasad HKC, Bhojwani KM, Shenoy V, Prasad SC. HIV manifestation in otolaryngology. Am J Otolaryngol - Head Neck Med Surg. 2006;179-85.

20. Soucek S, Michaels L. The ear in the acquired immunodeficiency syndrome: II. Clinical and audiologic investigation. Am J Otol. 1996;17(1):35-9.

21. Picton TW, Hillyard SA, Krausz HI, Galambos R. Human auditory evoked potentials. I. Evaluation of Components. Electroencephalogr Clin Neurophysiol. 1974;36:179-90.

22. Anders K, Guerra WF, Tomiyasu U, Rosen RJ, Telling S. The neuropathology of AIDS. UCLA experience and review. Am J Pathol. 1986;124:537-58.
23. Polich J, Ilan A, Poceta JS, Mitler MM, Darko DF. Neuroelectric assessment of HIV: EEG, ERP, and viral load. Int J Psychophysiol. 2000;38(1):97-108.

24. Tartar JL, Sheehan CM, Nash AJ, Starratt C, Puga A, Widmayer S. ERPs differ from neurometric tests in assessing HIV-associated cognitive deficit. Neuroreport. 2004;15(10): 1675-8.

25. Smith T, Jakobsen J, Gaub J, Helweg- Larsen S, Trojaborg W. Clinical and electrophysiological studies of human immunodeficiency virus - soropositive men without AIDS. Ann Neurol. 1988;23:295-7.

26. Vieira ABC, Greco DB, Teófilo MMM, Gonçalves DU. Manifestações otoneurológicas associadas à terapia antiretroviral. Rev Soc Bras Med Tropical. 2008;41(1):65-9. 